\title{
Footballers Image Rights in the New Media Age
}

Richard Haynes,

\section{Stirling Media Research Institute, University of Stirling.}

\section{r.b.haynes@stir.ac.uk}

Originally published: European Sports Management Quarterly, Vol. 7 (4), pp.361-374.

\begin{abstract}
Image rights, broadly defined as the commercial appropriation of someone's personality, including indices of their image, voice, name and signature, have become increasingly important in the political economy of media sport. A range of legal, economic and political arguments have developed in the UK as to what image rights actually are, their legal efficacy and their potential impact on developments in the long-standing relationship between sport and the media. This paper focuses on the problematic definition of the term in the UK context and how it relates to certain economic and commercial transformations in British football. Using the English Premier League and the 'celebrity footballer' David Beckham as its primary focus, the paper traces the rise of image rights clauses in player contracts. This process is analysed in the context of rapid and dramatic change in the media coverage of the sport. The paper focuses on the growing legal complexities of protecting star images in relation to the Internet and the wider issues of football, fandom and popular culture.
\end{abstract}


Beckham, or at least, the commodified Beckham, has profited from the same kinds of processes that create kings from fools, luminaries from dullards, It Girls from underachieving nymphets. All have been delivered to a vast audience courtesy of a media with a seemingly inexhaustible appetite for celebrities.

(Ellis Cashmore, 2002, p. 192)

\section{Introduction}

In the age of Beckham and Rooney, Ronaldo and Zidane, the attempt to commercially control both images and information around football has never been so great. For those players at the pinnacle of the sport the rewards of playing the professional game and the commercial trappings that accompany it are viewed as recognition that their worth is not purely born of how they play the game but also by their market value as a brand. As any economist will tell you, brands are notoriously difficult things to evaluate and are prone to fluctuations in the potency of their symbolic and capital worth (Thurlow \& Jaworski, 2006). Nevertheless, the elite of the world's footballers, the superstars of the game, are now traded on this intangible value with the capture of their so-called 'image rights' central to any contractual negotiations between player, agents, club and national federation.

This article intends to investigate the phenomenon of 'image rights' from both a critical perspective on intellectual property and more broadly through a critique of the political economy of sport and the media; that inseparable couplet that presents a marker of contemporary culture and entertainment at the start of the Twenty First Century. As a consequence, what is at stake is the decay of a certain aspect of football as popular culture that has matured through the origins of spectator sport and its mediated spectacle into something that millions of people enjoy and connect with on various levels. In other words, it is increasingly 
the case that significant sectors of football culture are being commodified through the enclosure of intellectual property rights, that encroach on areas of fandom and cultural practice that were once unrestrained or at least freer - in both senses of the word - than is currently the case. It is not that I would argue that things used to be better in the good old days, nor that sport stars should not enjoy the trappings of their successful careers. It is more that I fear that on economic grounds alone the football industry is in danger of killing the goose that laid the golden egg. As Morrow (2003) has documented, financial mismanagement by football clubs has seriously damaged the health of certain sectors of the professional sport in both England and Scotland largely due to exorbitant wage demands and an inability to keep a tight reign on the fiscal management of the game. The steady march to the hyper-commodification of sport has been happening for a long time and we should therefore not be surprised by its scale, predominantly expressed through the economic dependency of football and television (Boyle \& Haynes, 2000 \& 2004). Football needs television for the cash injection the rights of access to broadcast can bring. In negotiations over television rights contracts, broadcasters may well point to the public exposure they provide to the sport and the benefits such publicity affords. In the age of niche sports channels this argument loses some of its credibility. It is the economic rents football extracts from the relationship with television that underpins many of the strategic decisions made at the elite end of the professional game not the scale of its exposure. Television organisations need football for the ready-made audience and symbolic value it can bring to their channels in terms of ratings and subscriptions. These dual forces - the financial needs of football and the drawing power of football for broadcasters - represent the economic motivations behind the changes in elite professional football leagues around the world. Their consequences are deep seated and far 
reaching, and in my focus on one aspect of these processes, the rise of player image rights, I am suggesting that the balance between football as an industry and its consumers (the fans) is increasing tilted toward the economic imperatives and greed of the games' elite clubs and players.

\section{The New Football Economy}

In this short space it is pretty difficult to provide a wholly accurate portrait of the macro-economic environment of English club football, but what is clear is that a small elite of clubs gain enormous benefits from their commercial operations, while the majority struggle for their very existence. Even within the Premier League the disparities are incredibly marked and the influx of foreign ownership of key clubs by international billionaires including Manchester United by the Glazer family, Liverpool by the Gillette family and Chelsea by Roman Abromovich reveal a telling disjuncture and imbalance of wealth in the English league structure. Many other English clubs, not as fortunate have gone in to administration or suffered the indignity of losing all their best players to help stave off creditors and the Inland Revenue.

Both journalistic and academic investigations in to the financial management of the sport have reiterated the point that football at the elite end of the spectrum is so driven by commercial necessities and greed that outside the Premier League is an economic wasteland (Fynn \& Guest, 1994 and 1999; Conn, 1998 and 2004; Conn et al, 2003; Dempsey \& Reilly, 1998; Morrow, 1999 and 2003; Hamil et al, 1999 and 2000; Banks, 2002; and Bower, 2003). It is commonly held that the intensification of football as a commodity began in the early 1990s following the first broadcasting contract between the newly formed Premier League and payTV satellite broadcaster BSkyB. It might be argued, quite rightly, that the sport 
has always had ties to commercial activity from its origins as a spectator sport. Indeed, it could be suggested that the sport has experienced significant spurts of commercial activity since the rise of the football superstar in the late-1960s and again with the arrival of shirt sponsorship during the early attempts to televise league matches live in the mid-1980s. But none of these processes have had quite such a dramatic impact and altered the economics of the game as much as the era of satellite and pay television. Put simply, the elite end of professional football in England has become a new commodity managed by a new business class.

These economic changes went hand in hand with new pressures of governance of the professional game and the axis of power both within and beyond Premiership football involve some complex political relationships between clubs, the Premier League, the Football Association, the Football League and the international governing bodies UEFA and FIFA. Critics of the new era of commercialised football point to the distortion of wealth and power at the national (Manchester United, Chelsea and Arsenal) and supranational (the G14 group of European clubs) levels (see Williams, 1999, and Boyle \& Haynes, 2004) and the associated corruption and political ineptitude that accompanies the marketdriven, free enterprise culture that pervades increasing levels of the game (Bower, 2003 and Thomas, 2003). Clubs and football administrators would point out that any economic or political crisis that the game endures is largely born of the most significant power-shift in the world game: from clubs to players.

In an illuminating interview by Andrew Warshaw published on the FA's website the Chief Executive of UEFA, the Swede Lars-Christen Olsson, placed a significant emphasis on the destructive influence of what is more widely referred 
to as 'player power'. Olssen made a plea for more solidarity in the game between the key stakeholders, stating: 'What's terribly important is that football is bigger than any individual. When the key stars in European football disappear - whether they are players or officials - the game will survive. That's why we have a humble view of our own importance' (Warshaw, 2004). Behind the assertion is the belief that elite clubs are setting a destructive economic agenda for the sport by paying inflated salaries in order to capture the leading talent in the game (the core value). Experiences at Lazio in Italy and Leeds United in England (where the dream of European football and commercial success prompted the clubs board to financially extend themselves well beyond their means) reveal not only the cavalier nature in the financial management of some football clubs but also the rapacious tendency to cave in to the demands of players and their agents only too willing to join an 'aspirational' elite that pay 'top-dollar'. Leeds United fans learnt the hard way when the club ended up with $£ 100 m$ of debt and no trophies in the cabinet to celebrate. One of its top earners Mark Viduka had been bought through a complex set of contractual negotiations that saw the player's license his right to play for Leeds united in the English Premier League - underwritten by an insurance company rather than the club. $£ 20,000$ of Viduka's weekly wage of $£ 70,000$ was made up of payments for his image rights. Leeds ultimately became uncompetitive, lost all their talented players to pay off debt and lessen the wage burden and lost their Premier League status in 2004. Although extreme, an episode such as that involving Leeds United reveals the financial strain many clubs feel when trying to retain their international players and maintain their Premier League status. Innovative ways of paying player salaries has become a key practice of football accountancy and it is here that image rights come in to their own. 


\section{Players, contracts and image rights.}

The term image rights entered the consciousness of most British football fans in 2000 when Real Madrid made their then world record signing of Portuguese midfielder Luis Figo from arch-rivals Barcelona. Crucial to the negotiations was the retention of Figo's image rights by the club enabling Real to exploit the players name and image on their merchandise and share in the profit from any personal endorsements the player might attain from sponsorship or advertising. If footballers were ever perceived as commodities this was surely it. Real went on to negotiate similar image rights deals with a number of their so-called 'Gallacticos' - Zidane, Ronaldo and most prominently David Beckham - to underline the centrality of exploiting licensing contracts above and beyond their success on the field. Research published in September 2004 revealed Real to have the largest fan base in the world, reaching an estimated half a billion fans in 13 key 'football markets' (Soccer Investor, 2004). The key to this success is the combination of the Spanish clubs historic brand as supreme European champions with the global appeal of its many international stars. The sale of replica shirts dramatically boosted Real's turnover to $€ 300 \mathrm{~m}$ in 2003/04 and was mooted as the main reason for the transfer of David Beckham from Manchester United in July 2003 in an attempt to capture the fan market in South East Asia. As I shall discuss in more depth below, Beckham's voracious exploitation of his image and the various contractual and intellectual property rights associated with it stands as an extreme case of the commodification of football.

Less publicised image rights deals had also taken place in English club football. When Arsenal signed Denis Bergkamp from Inter Milan and David Platt from Sampdoria it enabled the club to include an image rights clause as part of their salaries. The key to the contracts was the ability for players to offset income tax 
and national insurance payments through earning commercial income sourced outside the practice of playing football. The players personal-image-rights company would enter into contractual negotiations with the club for the exploitation of the rights. Rather than paying income tax on the proportion of their salaries gained from endorsements and other commercial activities the players would only be due to pay capital gains tax (at a much lower rate) on this income a significantly diminished burden. Similarly, the club would not be due to pay any social security payments on payments for a players image rights.

Bergkamp and Platt were able to exploit this tax loophole because they were previously domiciled outside the UK. The practice was investigated by the Inland Revenue and the players were eventually taken to court. However, the judge ruled in favour of the players on the grounds that commercial revenue earned outside the UK is distinguishable from the core activity of their employment (namely playing football) and is not subject to UK income tax (Lewis et al, 2002). Following this ruling, many Premier League clubs instigated similar contractual deals with elite players and those signed from outside the UK. However, even players domiciled in the UK were able to develop image rights clauses by setting up investment trusts outside the UK - mainly in the Netherlands or the Republic of Ireland - where tax laws were more favorable.

These practices are now well ingrained into the transfer and contractual negotiations of players at the elite end of the game. Where once players were obliged to simply appear in the annual club photograph, have their image reproduced for bubble gum cards or sticker albums and do the occasional public relations stint at the local supermarket, contemporary footballers are groomed and managed with an array of support staff including agents, publicists, financial 
advisors and most importantly lawyers primed to exploit every available nookand-cranny of the football gravy train. In 2003 the Professional Footballers Association renewed its standard form agreement for players with Premier League clubs to include new regulations on image rights. Clubs were now obliged to include in their salaries specified payments for promotional and marketing activities undertaken by their players - whether they were megastars or not. The PFA have long claimed that players forego their performance rights in front of the TV cameras. Instead, the union levies a percentage of the income received by the Premier League, the FA and the Football League from television rights fees from all UK broadcasters. It is a mute point whether or not players could claim such performance rights under current copyright law in the UK (Arnold, 2002), but the threat of enforcing a 'blackout' in front of the cameras has certainly given the PFA a latent power in the negotiation over the levy of TV rights that enables the organisation to fund itself and underwrite player pensions and other benefits. The levy is born of the solidarity principle that all union members should be able to benefit from the funds and could be seen as one mechanism by which the money brought into the game by star players - through attracting inflated TV rights income - is redistributed to those in need. However, some players have investigated the possibility of exploiting broadcast rights for their own personal gain. When particularly important goals are replayed adinfinitum there has been a mounting argument for the player concerned (the scorer) to receive repeat fees for the rights to exploit their moment of magic (for example, Ryan Giggs pursued his performing rights over the repeated use of the footage of his FA Cup Semi-Final wining goal against Arsenal in 1999). It is argued that such uses are editorial. That is, they are not used in the context of the normal coverage of the game but are actually used to help promote the programmes or channels on which they are shown. Any solidarity principle would 
appear to disappear if such a situation arose and the burden of paying for such additional rights would no doubt ultimately fall on viewers.

\section{The Enclosure of Football Image Rights}

Boyle (2003) has consistently argued in respect of media corporations and copyright that we are witnessing a kind of 'enclosure movement' of informational goods and ideas based on an economic reasoning that argues that property rights provide control, maximise value and benefit those that become the guardians of the rights of access. In other words, the economic rhetoric behind intellectual property rights - its ideology - dictates the legal and technological environment in which the media now operate. In tandem with Boyle's critique I would argue that this process has also been prevalent in the sports industry, specifically at the intersection of sports stars, the media and promotional industries. For Boyle and others such as Lessig (2001), the enclosure movement is repressive because it closes down aspects of the commons - the public domain of free information and ideas - that used to be a valuable part of our popular culture. In football, commercial battles over the control and use of images are having a similar knock-on effect on the potential cultural creativity associated with the sport and its fandom. I shall expand upon this point shortly, but first it is important to understand how this enclosure has moved on apace in the past few years.

Until recently English courts had been reluctant to recognise any rights in personality as a means of securing exclusive rights to commercially exploit the proprietary right in someone's image, name, voice or likeness. Many stars have trade marks associated with their name - including BECKHAM and ROONEY but such trade marks in people's names are limited in their range of products and 
services they can cover (usually in categories $x, y, z$ ) and have been successfully challenged in the courts (for example Elvis Presley Enterprises Inc v Sid Shaw Elvisly Yours [1999]).

Nevertheless, in 2002 case law gave a fillip to British celebrities in a judgment involving Formula One racing driver Eddie Irvine. Irvine claimed damages against the radio station Talksport (at the time called Talk Radio) after his image was illegitimately used in a promotional campaign by the commercial broadcaster. Talksport had doctored an unconnected photograph of Irvine by replacing the image of him holding a mobile phone with that of a radio with the tag line "Talk Radio... we've got it covered". Irvine, clearly irked that he had not agreed to the use of his image, successfully sued for damages on the grounds of 'false endorsement': the argument that Talksport had deceived the viewers of the promotion that he had licensed the use of his image as a commercial endorsement of the product. Irvine succeeded under the tort of 'passing off', the defence against his name and likeness as an unregistered trademark. In making the judgment the court effectively recognised for the first time in English law that famous sports stars had a commercial right to the exploitation of their image. The ruling also caused ripples across the sports law community as the realisation dawned that their clients - a host of elite sports celebrities - had legal support for the protection of their image rights, at least to a point. The Irvine case fell short of giving a prima facie right of publicity - as exists in the United States and some European nations - but the ruling was a warning shot across the bows of any media organisation or advertiser that sought to leverage any commercial value from sport stars.

Similar cases confirmed the newly emerging recognition of image rights as a 
category of legal protection, including an out of court settlement between former England cricket star lan Botham and brewers of the Guinness brand Diageo after the brewers had used images of Botham's heroic performance during the 1984 Ashes series in one of their advertising campaigns. The threat of litigation following Irvine's intervention against Talksport had prompted the settlement, but it is certainly worthwhile questioning the motive of Botham and his advisors regarding any hold the player might have over archive footage. In copyright law it is the broadcaster that holds the rights to license secondary uses of the footage not the subject of the footage - in this case Botham. The fact that Botham's legal team were able to force the hand of Diageo emphasises an important sea change in how media organisations and advertisers view their commercial position to sports stars.

Legal precedents of this kind underpin the new regime of image rights in British football. This regime consists of an all-pervasive attitude among governing bodies, clubs, players and their agents that all - or certainly most - commercial and even non-commercial uses of images should be licensed and cleared accordingly. Such a legal enclosure of images potentially has some dramatic consequences for media, freedom of information and creativity in the new media age where production and consumption of digital images are increasingly blurred. It raises issues about football in the public domain as part of popular culture, and the rights of consumers and citizens. Examples of how this imbalance resides in the football industry now follows with an analysis of David Beckham and the management of his image rights.

\section{Policing the Image: The Case of David Beckham}

We have come to understand why footballers are paid handsomely - the 'prune 
juice' effect of tapping in to the flow of income from television rights that flows all the way in to their (and their agents') bank accounts. We also understand that they can afford specialist legal support that will seek to use existing laws to their benefit, either through trademarks or 'passing off'. But what are the actual practices of footballers in their attempts to control their commercial worth as celebrities? The opportunities to exploit a star footballers name and image are now wider and more lucrative than ever before. This process is born of two interrelated aspects of contemporary sports stardom that combine the widening of symbolic capital of sports stars in industrialised capitalist cultures and the increasing economic capital in the global media sports industry. How the symbolic world of culture links with the economic world of the sports industry is best explained through a specific example. Here I shall focus my attention on perhaps the exemplar of this process, the former Manchester United, Real Madrid and England footballer David Beckham.

In his dissection of the celebrity status of Beckham, Cashmore (2002) remarks that athletes were once admired for their status as heroes, bestowed because of their deeds. Today, the cult of celebrity seems to operate outside of the talent on display. Instead, celebrity status and the trappings that go with it are 'bestowed on them by others' (Cashmore, 2002, p. 174). This is a trick of contemporary media culture that reveals the most intimate details of the stars to a knowing and sometimes cynical public. And yet, their fans hang on every word, every gesture, every consumable product that bares their name and image. We dream about being them, about being rich and famous, and being a celebrity, through consuming them. 'This', Cashmore argues, 'is why we're guided to celebrities, why the media produce more of them, and why the market commodifies them' (Cashmore, 2002, p. 194). This sounds a long way from football fandom as it is 
traditionally conceived, but it explains why Real Madrid signed Beckham to capture his image rights to sell branded products to the 0.5 billion fans they reportedly have waiting in the wings, eager to snap up replica shirts and other merchandise and services. Beckham is an exceptional case in respect of image rights but the way in which his image has been commodified and its economic value policed is worth exploring a little further in this context.

In March 2004 Beckham the footballer became Beckham the logo, or more correctly, his 'trade mark' skill of scoring from free kicks was literally trade marked in a stylised logo of the player to accompany his range of branded merchandise for one of his main sponsors Adidas. The decision to use a dedicated logo for Beckham merchandise mirrored the characatured basketball player used by Nike in their long-standing and lucrative association with one of Beckham's long time heroes Michael Jordan (indeed on signing for Real Madrid Beckham made much stock out of his request for the squad number 23 , the number worn by Jordan). In launching the logo Beckham was cementing his contract with the sports manufacturer until 2008. A measure of just how important the dual branding of Adidas and Beckham had become was illustrated during the opening ceremony of the 2002 Commonwealth Games in Manchester. Beckham was the central performer of the opening ceremony carrying a talismanic torch in to the stadium. However, in spite of the fact that the organisers had created a 'clean' stadium, with no perimeter advertising or sponsorship, Beckham entered the spotlight wearing a pristine white tracksuit with the word Adidas emblazoned across his chest in silver sequins. With 9 million viewers in the UK and many millions more watching worldwide Beckham's PR stunt on behalf of his personal sponsor was both audacious and an epitome of the commodified athlete. The peculiarity that football does not figure in the Games epitomized the wider 
appeal the organizers were trying to achieve from inviting Beckham - then still associated with Manchester - to open the event.

In many ways this was the least we might have expected from Beckham's iconic position in Britain's sports culture and wider cult of celebrity. The media's attention on Beckham the celebrity had begun in 1997 after his relationship with Spice Girl Victoria Adam's became public quarry, and the 'Posh and Becks' narrative took hold of an ever-probing media industry and public gaze. As Cashmore makes clear, the pop star's experience of commercialising celebrity played a significant role in how Beckham and his advisors, particularly the agents SFX Sports part of the Clear Channel Communications group, dealt with his emerging fame. Lucrative endorsements followed with Pepsi, Police sunglasses, Rage computer games, Vodafone, Brylcream, Castrol Oil, Marks \& Spencer and others alongside his central sponsorship contract with Adidas. All the above are global mega-brands, all cashing in on and adding to the players emerging celebrity. Many of these deals were renewed once the player moved to Real Madrid and dramatically increased in value. Beckham’s salary at Madrid, £4.6m included a $50 \%$ image rights clause that gave the club half of any new deals Beckham entered in to as a Madrid player. Shortly after Beckham's signing Adidas reported a 350\% rise in replica Madrid shirts with the name 'Beckham 23' emblazoned on the back. For Beckham, his personal wealth was aided further by new tax laws introduced by the conservative Spanish government providing exclusion for migrant workers from the highest band of tax at $45 \%$; a boon for imported football stars. As I have already outlined, these commercial activities are viewed as separate from a players role as a footballer and in 2003 Beckham established Footwork Productions to operate as a holding company for his commercial operations based in Madrid. In its first year of operation the company 
had a turnover of $£ 8.7 \mathrm{~m}$ with Beckham pocketing $£ 6.7 \mathrm{~m}$ from profits (Walsh, Campbell \& Barnett, 2004) and at the end of 2006 Beckham was British football's top earner by some margin with an estimated personal wealth of $£ 87 \mathrm{~m}$ compared to the second richest British footballer Michael Owen (at £32m) (BBC Sport, 2007). Interestingly, in terms of where this net value comes from, in 2006 Beckham earned $£ 4.4 \mathrm{~m}$ from playing for Real Madrid and more than $£ 19 \mathrm{~m}$ from commercial endorsements.

Beckham's management of his media relations has also been impeccable. Again, lessons were probably learnt from his wife, in particular the way in which images of himself, his home and his family were released to the press. Exclusivity and controlled release of images has been the main way in which Beckham has leveraged revenue directly from the media. Rights to the Beckham's wedding in 1999 were sold exclusively to OK magazine in a deal worth $£ 1 \mathrm{~m}$ who negotiated similar deals with the Beckham's in their home and while on holiday in Barbados. Allegations that most photograph's of the couple appearing in Britain's tabloid newspapers heralded from one source, paparazzi photographer Jason Fraser, led to allegations that the Beckham's had entered an undisclosed deal with the photographer that meant he was given an exclusive 'tip-off' of where the couple would be in readiness for a 'staged' but seemingly 'snatched' set of photographs (Gibson, 2003). Even after the vilification he received after his sending off in the quarter final of the 1998 World Cup against Argentina, and the allegations of an affair with Rebecca Loos an employee of his then marketing agents SFX, Beckham's acute sense of image and fostering of goodwill towards his celebrity has been impressive. The 'Loos affair' prompted Beckham to cut his ties with the SFX agency that had done so much to foster his global brand. The departure from SFX reveals the ways in which contemporary celebrity footballers have to 
strategically manage their public affairs and handle what Huw Beverley-Smith (2002) refers to as their 'dignitary interests'. Such interests - often referred to as issues of privacy - are related to their commercial interests through the interrelated ties with a celebrity's reputation. Interests in reputation are essentially non-pecunary (non-economic) but they clearly have a relationship with the publicity value of a footballers image. Ironically, damage to a players reputation could have a negative effect on the value of their formal endorsements, while at the same time increasing the value of their image, particularly at times of distress, to the popular press and celebrity magazines. Beckham has so far been particularly adept at handling both sides of the equation, but the way in which his life is writ large in a very public sense and how that is managed has been instructive to new talent, such as Wayne Rooney, entering the contemporary world of football as an entertainment industry.

Beckham has not only been the exemplar of managing endorsement deals and public relations. Both he and his wife have vehemently policed the use of their name, likeness and image, challenging anyone or any organisation that dare contravene their status as valuable commodities. In 2003 amid early rumours that Beckham would be moving to Spain to join Real Madrid the low cost airline Easyjet used a photograph of the player with one of his many changing hairstyles with the tag line 'Hair today. Gone tomorrow'. Although the advert made no illusion that Beckham had endorsed the advert - which is clear from the humorous nature of the ad - Beckham's agent SFX pressured the airline in to donating money to a charity of his choosing. Underlying the pressure was a threat to sue for possible false endorsement. The airline had a further run in with Beckham when they launched a second related campaign using the players' image. Once again, the image of Beckham, styled with another hairstyle, 
accompanied the tag line 'Not sure where to go this summer? Barcelona? Madrid? Milan? Lowest fares to the hottest cities'. Again, the advert made reference to the initial speculation as to Beckham's future before he eventually signed for Madrid. Easyjet's behaviour flags up the insecure legal ground celebrities in the UK have to challenge the use of images by advertisers that are already in the public domain and that because of the humorous content implicitly communicate to the public that the star has not actually endorsed the product or service.

In another episode, Victoria Beckham was alleged to have 'gone mental' in a souvenir shop in London where the pop star had spotted what she believed to be fake signed photographs of her husband on sale in the store. The encounter received wide coverage in the national press and led to considerable loss of trade for the shop owners Timothy and Glynis McManus. The couple filed a suit against Beckham claiming damages for slander. The case was heard in the high Court and Beckham was ordered to pay $£ 88,000$ in damages. Other instances of image and trademark policing of the Beckham brand have taken place on the global stage. A Russian company was threatened for using a look-a-like actor, clearly intended to be perceived as Beckham in an advert for cans of 'Manchester Gin'. The campaign was viewed as a clear case of passing off by the drinks manufacturer and Beckham's new management company, 19, investigated the possibility of taking the matter to a Russian court under reciprocal agreements under the World Trade Organisations key multilateral agreement on intellectual property known as TRIPS (Trade Related Aspects of Intellectual Property Rights). In his attempt to leverage his notoriety as a global brand, Beckham has registered his name as a trade mark in every territory around the world where such intellectual property laws exist. 
In another much publicised legal action involving Beckham's wife, Victoria tried to halt the registration of the word 'Posh' by the football club Peterborough United. The club had commonly been known as 'the Posh' since the 1930s and in 1998 had sought to register a trademark of its nickname for merchandising purposes. Victoria Beckham, also known to the public as 'Posh Spice' claimed that her moniker as Posh was far more ubiquitous and had more recognition among the UK population than the football clubs claim to its 'badge of origin'. In January 2004 Beckham eventually rescinded the allegations and admitted defeat, the clubs eighty-year history of trading under the name too entrenched to be overturned by Beckham's more ephemeral status as a celebrity.

In February 2007 Beckham signed a five-year deal with the US Major League Soccer franchise LA Galaxy reported to be worth $\$ 250 \mathrm{~m}$ over five years, although the guaranteed income was much less at $\$ 6.5 \mathrm{~m}$ per year (L' Hote, 2007). The move may prove apocryphal as the most blatant commercial transfer in the history of football. While some may argue that moving to the US would not undermine the players standing as a global footballing talent, many observers saw the move as a clear sign that Beckham the celebrity was now a far more potent symbol than Beckham the football player. The transfer to Los Angeles was partially prompted by a breakdown in contractual negotiations at Real Madrid over the control of image rights. Beckham had sought assurances from Florentino Perez, the outgoing president of the club, that he would take complete ownership of any income from non-footballing related endorsements. This would have broken Madrid's policy of dividing the commercial income of their 'galacticos' 50:50. 
In moving to the US Beckham also moved into a legal environment where the economic worth of his media image is protected under the First Amendment 'rights in publicity' and he has a proprietary right to own $100 \%$ of the commercial use of his image or name. Under MLS rules, the League contracts all players centrally and retains ownership of any rights connected with the League. The MLS pays a standard fee of $\$ 400,000$ and the players club shoulders the cost of the remaining salary and bonuses. However, Los Angeles is arguably the global epicentre of celebrity culture and the Beckham's move into the safe waters of Hollywood and media endorsements will enable him to grow his personal commercial deals and secure the players standing as one of the wealthiest sportsmen in the world.

\section{Conclusion}

The attempt by professional footballers to commercially control images and other information about soccer is happening at a time of expansion in the communication of all things related to the game. More broadly, legal critics such as Lessig (2001) have argued that innovations in new media are potentially being undermined by the enclosure of intellectual property rights. Sport, most notably football, has been one of the most vociferous industries in protecting images, data and relevant commercial information from escaping in to the public domain. In my brief overview of contemporary practices in the English football industry it is clear that economic and legal issues are increasingly at the forefront of any communications connected with the sport. Awash with money from television rights and sponsors the games' position in popular culture and the relationship between players and clubs, players and fans, and clubs and fans have been redrawn. In the brief overview of David Beckham's career as a celebrity and brand, we see a level of economic and legal intervention in the life of professional 
footballers and their relationship with the media and their audience that is markedly changed from previous eras of the sport. At a time when new media networks such as the Internet offer promising avenues for fans to engage with the sport, through fan websites and specialised weblogs, the football industry and the intermediaries that provide the support systems now required to sustain its business (for example, lawyers, agents, financial advisors, publicists) increasingly view fans not as part of the spectacle but as consumers. One central aspect of fandom requires an engagement with media images of the object of their desire. The contemporary cult of celebrity that now surrounds football certainly fills this need. However, fandom is also about the appropriation of images and information to make new cultural meanings and produce new cultural artifacts. For example, when a young fan sets up a website in honour of their football hero or produces a mashup of famous goals for YouTube or MySpace they do not expect to find a legal writ on their doorstep disputing their right to have registered a domain name associated with the player or for having infringed copyright. However, this is increasingly a common occurrence as football clubs and players, bolstered by a new found legal remedy under World Intellectual Property Organisation's domain name arbitration procedures are used to force unsuspecting individuals who merely wanted to celebrate their fandom in a creative way. WIPO's arbitration service tends to favour the individual or organisation that holds a registered trademark and there have been a series of rulings that have reclaimed football related domain names back to players or their clubs. While some elements of 'cybersquatting' - the parasitical activity of extorting money from trade mark owners through the registration of related domain names - does exist and is rightly deemed an act of bad faith, it does not mean that all associations with a players name or club are for commercial gain or 
of harm to their reputations.

The images and names in sport are not merely economic assets to be exploited, but are embedded more generally in the cultures of sport. In the case I have argued above British soccer is seemingly rewriting its cultural contract between football and its fans. As footballers get sucked more and more into the media dominated entertainment industries this has primarily occurred along commercial lines protected by intellectual property law as it is in the film, television, music and associated industries. Ultimately, the economic imperatives of the football industry are generated from the core value of the sport, its new breed of football celebrities. As the market for all things related to football appears to grow exponentially - in television, sponsorship, advertising and merchandising - it may seem absurd to signal the symbolic 'death of football'. But as each crevice of football culture becomes commodified and commercialized the historic organic ties within sport between clubs, players and supporters that are at the root of multiple meanings in the game become strained. There is evidence of a new cynicism around football, not least by those who earn their living off the back of it. The Guardian sports journalist Will Buckley, author of a book entitled The Man Who Hated Football, summed up this rising sentiment regarding the over-baring nature of football in British popular culture when he suggested: "if everyone could start to take football a mite less seriously, there is a slim chance it might become a degree more joyous" (Buckley, 2004). But while football remains serious business, the joie-de-vivre associated with football's wider social and cultural place in society will be increasingly challenged. 
Bibliography

Arnold, R. (2002). Copyright in Sporting Events and Broadcasts or Film of Sporting Events after Norowzian. In E. Barendt \& A. Firth (Eds.), The Yearbook of Copyright and Media Law 2002 (pp. 51-60), Oxford: Oxford University Press.

Banks, S. (2002). Going Down: football in crisis. Edinburgh \& London: Mainstream.

BBC Sport (2007). Beckham tops football's rich list. http://news.bbc.co.uk/sport1/hi/football/6212696.stm

Beverley-Smith, H. (2002). The Commercial Appropriation of Personality. Cambridge: Cambridge University Press.

Bower, T. (2003a). Broken Dreams: Vanity, greed and the souring of British football. London: Simon \& Schuster.

Boyle, J. (2003). The Second Enclosure Movement and the Construction of the Public Domain. Law and Contemporary Problems, Winter/Spring 2003 (1 \& 2), 33

- 74. http://www.law.duke.edu/journals/lcp/indexpd.htm

Boyle, R. \& R. Haynes (2000). Power Play: Sport, the Media and Popular Culture. Harlow: Pearson.

Boyle, R. \& R. Haynes (2004). Football in the New Media Age. London: Routledge. 
Bower, T. (2003). Broken Dreams: Vanity, greed and the souring of British football. London: Simon \& Schuster.

Buckley, W. (2004). Why I'm not singing any more. The Guardian, 5 May 2004.

Cashmore, E. (2002). Beckham. Cambridge: Polity.

Conn, D. (1998). The Football Business: Fair Game in the 90s. London \& Edinburgh: Mainstream.

Conn, D. Green, C. Mcllroy, R. \& Mousley, K. (2003). Football Confidential 2:

Scams, Scandals and Screw Ups. London: BBC Worldwide.

Dempsey, P. and Reilly, K. (1998). Big Money Beautiful Game. London: Nicholas Brealey.

Elvis Presley Enterprises Inc v Sid Shaw Elvisly Yours [1999] RPC 567 (CA)

Fynn, A. \& Guest, L. (1994). Out of Time. London: Simon \& Schuster.

Fynn, A. \& Guest, L (1999). For Love or Money: Manchester United and England - the business of winning. London: Andre Deutsch.

Gibson, O. (2003). Beckham denies paparazzi deal. The Guardian, 16 April 2003.

Hamil, S., Michie, J. \& Oughton, C. (Eds.), (1999). The Business of Football: $A$ 
Game of two Halves? Edinburgh \& London: Mainstream.

Hamil, S., Michie, J. Oughton, C. \& Warby, S. (Eds.), (2000). Football in the Digital Age: Whose game is it anyway? Edinburgh \& London: Mainstream.

Lessig, L. (2001). The Future of Ideas: The future of the commons in a connected world. New York: Random House.

Lewis, A., A. Bell, C. Chilvers, C. Flint, C. Weir, C. Lawrence \& J. Taylor (Eds.), (2002). Sport: Law and Practice. London: LexisNexis Butterworths Tolley.

L' Hote, J. (2007). Soccer Nation? Sport Business International. July 2007 (125), $54-55$.

Morrow, S. (1999). The New Business of Football: Accountability and Finance in Football. London: Macmillan.

Morrow, S. (2003). The People's Game? Football, Finance and Society. Basingstoke: Palgrave Macmillan.

Thurlow, C. \& Jaworski, A. (2006). The alchemy of the upwardly mobile: symbolic capital and the stylization of elites in frequent-flyer programmes. Discourse \& Society. Vol. 17 (1), 99 - 135.

Walsh, C., Campbell, D. \& Barnett, A. (2004). Offside! England stars blasted for avoiding tax on fortune from TV ads. The Observer, 6 June 2004. 
